\title{
Individual Character: Towards Empirical Investigation
}

\author{
Weragoda, R. B. L ${ }^{1}$, Opatha, H. H. D. N. $\mathrm{P}^{1}$ \\ ${ }^{1}$ Department of Human Resource Management, University of Jayewardenepura, Sri Lanka \\ Correspondence: Weragoda, R. B. L, Department of Human Resource Management, University of Sri Jayewardenepura, \\ Sri Lanka, E -mail: lweragoda2000@yahoo.com
}

Received: March 18, 2016

Accepted: April 3, $2016 \quad$ Online Published: May 11, 2016

doi:10.5539/ibr.v9n7p55

URL: http://dx.doi.org/10.5539/ibr.v9n7p55

\begin{abstract}
The study of individual character is an essential area for organizational research as it is instrumental in ensuring ethical behavior at individual and organization level. However it is observed in the literature that this area has been largely untapped and especially moral and social dimensions of character have been ignored in contemporary studies. Further, it is observed that character and related terms, i.e. virtues, morality, ethos and values have been widely used interchangeably due to conceptual ambiguity (the ontological basis) and certain instruments used for empirical investigations potentially suffer due to methodological ambiguity (the epistemological basis) of the construct. In this paper, we have formulated a conceptually sound definition which provides a clear direction for future empirical investigations and facilitates to differentiate individual character from other related terms. Finally, we propose certain missing and new dimensions of individual character and recommend promising research directions in order to further expand content validity of the construct.
\end{abstract}

Keywords: character, character strength, ethos, morality, virtues

\section{Introduction}

The moral philosophy combines three principal elements: deontology, teleology, and virtue ethics (Thun \& Kelloway, 2011).According to Garofalo (2003), deontology refers to an ethical position and stresses that principles are determinative rather than consequences, in estimating moral goodness of an act. Teleology concerns achievement of designated objectives of an act. As per Garofalo (2003), worth of moral act, depends on the consequence of such act. The final component: virtue ethics which stresses the morality of an act is determined by the character (Garofalo, 2003). Underlining interdependency among principle, consequence, and character may form the foundation of moral philosophy. The word virtue has derived from the Latin term: virtus which is employed by Latin authors to translate the Greek term arete, originally denotes the excellence of human qualities (Yu, 1998) and virtue is a powerful illustrative term in the moral philosophy. Aristotelian virtues include liberality of patron, bravery of inhabitant, benevolence and attentiveness of relatives, and temperance of non-lascivious life (Sherman, 1989) which cover all facets of a person's life in order to ensure widely acceptable pattern for human actions in a consistent manner. Individual character is an expression of virtues that disposes with habitual course of actions (Lapsley\& Narvaez, 2006). Simply, individual character comprises of those virtuous characteristics which lead a person to think about wrong things, do the right thing, and finally engage in right behavior. Virtues and individual character are highly interdependent and mutually implicative. A good individual character, which we expect from all citizens including leaders, managers, and employees to thrive organizations or the society, is governed by a set of well-established virtues. Therefore character is instrumental in establishing ethical behavior at an individual level which in return facilitates to promote an ethical organization and finally an ethical society at large.

However, despite the importance of individual character as the fountain of ethical behavior, scholars largely have neglected this topic (Park \& Peterson, 2009). Further, it is observed very clearly in the recent literature of individual character, that historically significant social and ethical dimensions have been neglected (Wright \& Goodstein, 2007; Wright \& Huang, 2008; Quick \& Wright, 2011, Wright \& Lauer, 2013, Davidson et al., 2008). According to Wright and Goodstein (2007) there is a visible decline of research interest on moral and social dimensions of character rather contemporary character studies which are more focused on personal and individual competence dimensions and values i.e. a comfortable life, inner harmony, pleasure, ambition etc. Basically value-based research which excessively spread recently, more focuses only on self-related character dimensions (Wright \& Goodstein, 2007; Quick \& Wright, 2011). This trend of self-interest focus, coupled with an apparent lack of moral standards in value-based research is identified as one of the critical limitations of contemporary studies on character (Wright \& Goodstein, 2007). As an example, 
Peterson and Seligman's (2004) character strengths framework which is considered as one of the promising research outcomes, also potentially suffers due to the above limitation (Wright \& Huang, 2008). On the other hand, it is one of the contemporary issues in the society where, declining the moral aspects of individual character affects advancement of society (Wright \&Lauer, 2013; Opatha, 2010; Wright \&Huang 2008; Wright \& Goodstein, 2007; Pearson \&Porath, 2005). Giacalone and Promislo (2013) identified this trend as a crisis and stated that many individuals today are not only becoming morally bankrupts themselves, but also are more willing to ridicule others whom they view as living moral lives. Further, Wright and Goodstein (2007) identified this issue in education sector and state that the possible reason for currently wide spread student cheating and academic dishonesty resulting in unethical business practices is moral and character deterioration.

Social and ethical aspects derived from classical moral account are inseparable dimensions of character. Studying character negating moral and social dimension is detrimental in terms of enhancing content validity of the construct and most importantly application of scientific knowledge to establish a moral society. In this study, we examine these conceptual, empirical and practical issues of individual character in-depth, highlighting their possible implications from ontological and epistemological points of views. Therefore, the purpose of this paper is fourfold. First, we attempt to further clarify terminological aspects of character more comprehensively to clarify current definitional ambiguities; second, we propose certain missing and new dimensions of individual character in order to address current conceptual issues of character studies; third, we discuss epistemological aspects of character in order to enhance content validity of empirical investigations and finally we propose directions in designing instruments to assess individual character and promising research directions for organizational scholars to expand nomological network of the construct.

\section{Methodology}

As stated in the section one, the overall purpose of this study is to review identified ontological and epistemological gaps related to the review topic in order to provide clear direction for empirical investigations. Accordingly, the archival method, recommended by Tranfield et al., (2003) was deployed as the most appropriate method for this study. This method facilitated to build up a reliable knowledge base related to the individual character. The systematic review of literature started with general search of articles, conference proceedings, and edited book chapters published in online databases i.e. Sage, Springer link, Wiley online Library, Emerald in addition to printed text books and publications. Initially, different combinations of key words: character, individual character, character strength, ethos, morality, virtues were used in the search. Reading through the abstracts of around 90 articles and book chapters related to the construct, we selected about 40 research articles and number of edited book chapters directly related to the topic, which were studied in detail.

\section{Terminology of Character}

Defining character is a challenging task as meaning of character is confused specially in the recent literature (Lapsley\& Narvaez, 2006; Wright \& Goodstein, 2007; Wright \& Huang, 2008; Wright \& Lauer, 2013). Therefore, providing a better definition for the construct is the first step of further investigation (Hannah \&Avolio, 2011) in order to reflect native characteristics of the construct and differentiate the construct from the other related terms. Term character is derived from Greek word which denotes, 'mark or to symbol (Lapsley\& Narvaez, 2006). Aristotle, the progenitor of character theory says that, character encompasses person's enduring traits: attitudes, sensibilities, and beliefs (Sherman, 1989) that acknowledge the consistency and predictability of character. James (1920) explains character as specific mental and moral attitudes that facilitate individuals to feel deep and being alive. According to James, such inspiring attitudes symbolize one's inner voice and facilitate to identify the one's own self. Jame's explanation of character emphasizes inherited individual nature of character and how character affects person to see, act, and indeed reflect one's true nature of life. In the same vein, Likona (1991) defines character as taking right actions irrespective of external pressure. Etzioni (1996) refers to character as the capacity for self-discipline and empathy. Baumrind (1998) refers to character as positive traits that lead to desire and pursue the good. Berkowitz (2002) identifies character as one's psychological characteristics that affect person's ability and facilitate to function morally. Park et al., (2004) defined character as positive traits reflected in thoughts, feelings and behaviors which emphasize on how to reflect character from various human functions. A common issue of the above definitions of character is that the above definitions represent only individual based positive attributes but social dimension of character has been neglected.

In this paper it is acknowledged that both ethical as well as social dimensions of character influence the expression of one's character. Accordingly, Opatha (2007 p. 3) defined character as the "aggregate of all relatively persistent moral qualities that combines to form a person's real nature". The above definition reflects relationship between character and behavior and recognizes moral qualities as the foundation of character. The important aspect of the classical definition of character is moral discipline which refers a person's ability to manage his or her personal interests on behalf of a greater societal good (Hunter, 2000; Wright \& Goodstein; 2007; Wright \& Huang, 2008, Wright \& Quick, 2011). Moral 
discipline is an essential attribute of character which guides one's inner consciousness to comply with explicit moral standards oriented towards better common society. According to Hunter (2000), second aspect of character: moral attachment reflects the affirmation of individual's commitment to a larger community. This aspect is vital as it reflects individual's eagerness and willingness to commit for the betterment of larger community. The final aspect of character is moral autonomy which refers to individual's ability of making ethical decisions freely (Wright \& Goodstein; 2007). Individuals with high moral autonomy demonstrate voluntary agreement to act morally and reflective engagement of morality on continuous basis. Moral autonomy means that a person has both the necessary discretion and the ability of judgment at their disposal to freely act morally. They freely express their moral will and play catalyst role in the society. In line with the above conceptualization, Wright and Goodstein (2007, p. 932) defined character as "those interpenetrable and habitual qualities within individuals and applicable to organizations that both constrain and lead them to desire and pursue personal and societal good" The key aspect of the above definition is that such character qualities should be transmittable and inextricably linked with individuals' lives and facilitate to take life decisions considering both individual as well as organizational / community needs. Therefore character is a higher order construct which reflects an individual's degree of possession of virtues. Based on the previous work done by number of scholars specially Hunter (2000), Wright and Goodstein (2007) and Opatha (2007) we define character as relatively persistent and interpenetrable qualities of an individual which include both personal virtues and social virtues that facilitate to form and assess that individual's real behavior. This definition denotes number of essential aspects of character: 1 . Recognize duality of character: social and individual aspects, 2. Consistency and predictability of character, 3. Relationship of character and virtues 4. Inextricable linkage between character and individual behavior and 5. How character operates as a moral indicator. Providing an adequate definition for character is a considerable achievement as meaning of the construct is distorted in the literature (Wright \& Goodstein, 2007). Thus we believe that the above definition provides a clear direction for empirical investigations. In the next section we will differentiate character from other related constructs in order to recognize conceptual boundaries of the construct.

\section{Character and Related Terms}

It is now accepted that character and personality are two different constructs (Opatha, 2007; Opatha, 2010, Hannah \& Avolio, 2011a; Quick \& Wright, 2011). Generally personality refers to individual differences in characteristic patterns of thinking, feeling, and behavior. Opatha (2007) compares character with personality and states that in terms of personality, individual differences are acceptable. However, under the character being different is unacceptable as character is driven by universally acceptable virtues. For an instance, trustworthiness is a universally acceptable virtue equally applicable across all cultures, societies and time horizons. More to the point, Hannah and Avolio (2011) suggested that character may be structured and operated like personality, however it is not possible to equate the two, at least with common static trait-based notions of personality. We acknowledge the fact that individual character varies from person to person depending on the individual strength of character. As an example, individuals with higher moral potency may tend to pay more attention on ethical aspects in personal decision making irrespective of possible individual advantages or disadvantages. However there is only one desirable character: 'good character' which reflects from the individuals who uphold high extent virtues. In contrast, there are different personality types and their desirability depends on the specific demands of the given context. In a nutshell character is context neutral and personality is context specific.

Even though it appears in the literature that character and values have been used interchangeably as similar terms (e.g. Collins, 2001; Covey, 1999; Andersson \& Pearson, 1999; Lickona, 1991; Rokeach, 1973) both are quite different constructs. The concept of values has a number of meanings in social science. The word 'value' is relatively new to English language and just before World War II appeared in the Oxford English Dictionary (Himmelfarb, 1994).According to Rokeach (1973), values are specific and on enduring mode of conduct that facilitates to take personally or socially preferable decisions. Further, Rokeach identifies two categories of values: 1 . instrumental values which include moral and competence, 2. terminal values which include personal and social values. However, Wright and Goodstein (2007) argue that values are not enduring and primarily involve in an individual's personal outlook and beliefs about what should be desirable. Beyer (1981) defines values, from organizational perspective, as "rationalized normative systems of preferences for certain courses of action or certain outcomes" (Beyer, 1981, p.166).Values primarily involve an individual's opinions and beliefs about what should be or what is appropriate (Beyer, 1981). In other words, values are not basically considered to be either consistent or static entities and depend on the individual's view. Therefore they are typically contextually determined. While values are individual specific guides for individual satisfaction or individual wellbeing, virtues are for both the good life for individuals as well as overall well-being of the entire society. It is apparent in recent literature in social science that moral based character studies are reasonably declined as propagation of self-interest value studies which concern with individual needs and competences (Wright \& Wright, 2001; Quick \& Wright, 2011). Irrespective of these apparent conceptual limitations, acceptance of the term 
values by both academic and society as the moral code directly affects declining moral standards of the contemporary society (Wright \& Lauer, 2013). This trend of value based research in organizational studies bears a significant cost as many individuals tend to view now moral issues only from an instrumental or utilitarian point of views (Wright \& Wright, 2001). As we proposed a comprehensive definition for individual character and differentiate character from related terms in section three and four, we intend to further examine the dimensions of individual character in the section five, in order to develop a holistic view of character.

\section{Dimensions of Character}

According to literature, there are various ways to approach individual character. Hannah and Avolio (2011a) describe character as an underlining process of leadership; Opatha (2007) views as a unitary or categorical element; Peterson and Seligman (2004) explain character as a positive trait; Barlow et al., (2003) suggest as a leadership trait etc. Accordingly, Peterson and Seligman (2004) state that character is residing within the individual and serves as a source of behavior. Further, character is natively a plural or a multidimensional construct (Peterson \& Park, 2006). Peterson and Seligman (2004) distinguish that character exists at three levels in their Values In Action Inventory of Strengths model (VIA-IS). In this model the first conceptual level is called virtues which are described as broad-band, socially desirable, individual difference constructs that are valued across cultures. Accordingly, they identify six categories of virtues: wisdom, courage, humanity, justice, temperance and transcendence which should be presented at higher threshold level for an individual to be deemed of good character. Because of the abstract nature of the above identified virtues, Peterson and Seligman (2004) suggest further focus on the second level of conceptualization known as character strengths. In their framework, character strengths are the psychological mechanisms that define virtues. As an example virtue of wisdom can be reached through strength of curiosity and love for learning, judgment, creativity, and personal intelligence. According to Peterson and Seligman (2004) and Peterson and Park (2006) character strengths are always recognized and valued, whether a particular individual will display them all. Peterson and Seligman (2004) identify 24 strengths and propose that individuals can be considered of good character if they demonstrate at least one or two strengths within each virtue group. The final level of conceptualization of this model involves situational themes which are defined as specific habits that guide people to manifest given character strengths in a given context (Peterson \& Seligman, 2004). These situational themes are context specific and highly similar to values (Wright \& Goodstein, 2007). Therefore, it is clear that the first level broad band six virtues of the VIA-IS model are measured at the final level as values. However, according to Opatha (2007) values and virtues are two different constructs. Values are considered as relative construct while virtues are considered as absolute and universal construct (Opatha, 2010). Some values of a community may be harmful to others. In contrast virtues will never be harmful to others. Thus it appears that VIA-IS model proposed by Peterson and Seligman (2004) gets potentially suffered as virtue and value confusion reflected at the third level of conceptualization.

According to classic moral accounts of character; virtues, habits, and traits lay the basic foundation of character (Lapsley \& Narvaez, 2006). A virtue refers to "any psychological process that enables a person to think and act so as to benefit him or her-self and society" (McCullough \& Snyder 2000, p.1). In Nichomachean Ethics, Aristotle (2000) argues that virtues are not a natural part of the human activity rather person must earn as a result of continuous habituation. More preciously, Aristotle points out that virtues lie in between excess and defect of expected resources and intermediate one's passions, appetites and actions. This reflects the crucial role of the virtues in directing human behavior. It is important to note that, Aristotelian theory of habituation is totally compatible with contemporary models of cognitive science (Lapsley \& Narvaez, 2006). Based on the above conceptual evidences, it can be epitomized that virtues guide individuals for praiseworthy actions which benefit for self, others and society at large. Possession and application of virtues willingly on continuous basis facilitate to build praiseworthy habits which denote one's degree of alignment with virtues. Habits are repeated actions that a person does in a regular basis. Virtues, traits and habits are interdependent and highly mutually implicative in formation of individual character (Lapsley \& Narvaez, 2006). Therefore degree of alignment with virtues is disposing a person's habitual courses of action. Trait refers to durable or 'build-in' characteristics of a person (Veenhoven, 1994). According to Veenhoven, there are three stringent characteristics of traits: i. temporal stability, ii. cross-situational consistency, iii. internal causation. In terms of consistency and stability, traits are stronger than habits. Based on the above, it can be further epitomized that there is a hierarchical order among virtues, praiseworthy habits and praiseworthy traits where virtues provide directions for praiseworthy habits and long-run application of praiseworthy habits on continuous basis lays the foundation for praiseworthy traits. A person acquires virtues by practicing them and learns what virtues are by acting virtuously (Lapsley \& Narvaez, 2006). More to the point, Hannah and Avolio (2011a) stated that, leader can develop a larger part of the character through social learning. As character is driven by virtues (Opatha, 2007; Sarros et al., 2006), virtues provide moral direction for praiseworthy habits and praiseworthy traits and totality among these three aspect reflect one's character. 
Hannah and Avolio, (2011b) elaborate character from different point of views while ensuring requirements of classical and moral account of character. According to them, character remains a fuzzy construct and partly metaphysical in nature. From the ontological perspective, they attempt to identify character as a locus of leadership. They used meta-framework of the 'locus' the 'transmission' and the 'reception' of leadership to elaborate relationship between leadership and character. Locus of leader character is defined as representing internal moral aspects of the leader and transmission entails the ensuring of behavior required for the respective situation. Reception concerns on how those transmissions are received by the person. They propose character as an antecedent of transmission and reception of leadership. Further they stated that there may be 'process losses' between the locus and the transmission of ethical leader behavior due to various reasons, i.e. individual character strengths and contextual factors and attempted to point out the degree of exclusiveness between leadership and character. Most importantly, Hannah and Avolio (2011) stated that cognitive moral development is not sufficient to reduce 'process losses' and that leader moral development requires moral courage, moral efficacy and moral agency which is called moral potency to reduce 'process losses' between locus of character and character application (transmission). The above elaboration of Hannah and Avolio, (2011b) on individual character is important in developing character measurement instrument for empirical investigation. Even though character is identified as an individual level phenomenon, number of researchers recognized as an intra-individual construct considering the interdependency nature of character based leader and follower relationship (e.g. Hannah \& Avolio, 2011b; Neubert et al., 2009). The metaphor proposed by Hannah and Avolio (2011b): locus, transmission and reception reflect how strength of character transmits into action, especially how and why character strength declines in certain instances.

Moreover Hannah and Avolio (2011a) proposed additional level of character called ethos which denote extreme level of character derived from classic moral theory. In the Nicomachean Ethics Aristotle (2000) identified three sources where high level of ethos derived: practical skills and wisdom, virtue and goodness, and goodwill toward others. Hannah and Avolio (2011a) identified ethos as an inner strength that drives virtue and proposes to be considered as a distinct class of character which may not represent in high score of character measurement. Further, they proposed that extremely high level of character which is known as ethos will operate more forcefully under the condition of high moral intensity. According to Hannah and Avolio (2011a) character framework, there is a linear relationship between character and behavior up to individual's transactional ethical behavior. However there is no such linear relationship beyond transactional level where ethos begins to operate most forcefully under conditions of high moral intensity. Based on the above conceptualization, they explain how leaders operate in an extreme context where a leader tends to take personal risk or sacrifice self for the betterment of others. In summary, Hannah and Avolio (2011a) model of character points out meta-physical nature of character and how ethos inspire virtuous behavior at extreme level of character.

Ancient Greeks recognize two types of virtues: intellectual virtues and civic virtues and for them both types of virtues are equally important (Facione, 2000). More to the point, Opatha (2007) categorizes virtues into two areas: personal virtues and social virtues. According to him, personal virtues are highly individual related and more focused on person's development, i.e. patience, self-discipline, tolerance, loyalty. Social virtues are socially-oriented good attributes which are more group-related, more for others' development, qualities towards others and socially desirable qualities i.e. hospitality, benevolence, courteousness, compassionateness, trustworthiness, generosity, respect and gentleness. Further Opatha (2007) stated that both social and personal virtues are important to become a person with high degree of character.

In addition to cultivating higher virtues, Opatha (2010) stated that vices which are defined as serious moral faults in someone's character need to be eradicated or at least alleviated in order to develop a higher level of good character. In Aristotle's ethical theory, this aspect is addressed and stated that character comprises both virtues and vices (Sherman, 1989). Accordingly vices can be considered as the missing element of contemporary studies of character. Therefore alleviation of vices i.e. jealousy, greed, anger, stinginess, doubt, deception, corruption, retaliation is equally important as aligning with virtues. Highest level of character refers to application of maximum extent of virtues and none existence of vices (Opatha, 2010). It is possible that one can maximize both virtues and vices simultaneously. For an instance, a person can maximize trustworthiness or loyalty while continuing with jealousy or anger. Therefore we acknowledge that both virtues and vices are character dimensions which need to be considered for character development as well as character based empirical investigations.

\section{Character Measurements}

Character is subject to quantification (Thorndike, 1940; Barlow et al., 2003). As an example, locus, transmission and reception framework proposed by Hannah and Avolio (2011) and widely used VIA-IS model developed by Peterson and Seligman (2004) are represented in natural science platform. Even though there is a metaphysical aspect in the character, according to Quick and Wright (2011) such component of character falls more within the domain of application of character. However, from an epistemological point of view, character cannot be fully studied with current research 
methods and it requires further studies (Hannah \& Avolio, 2011). Therefore in line with our conceptualization of character in this paper, we acknowledge that character dimensions: virtues, praiseworthy habits and praiseworthy traits are subjected for empirical investigations. However, we disagree with certain current practices of estimating moral knowledge of a person and interpret the same as character. Simply knowing what right is and what wrong has no guarantee that someone will take right actions. Character can metaphor as a deeply engraved symbol of a person left by life that one can be differentiated from others. Therefore as per our definition given in this paper, it is essential to estimate interpenetrable qualities of an individual which include virtues, praiseworthy habits and praiseworthy traits to capture the real essence of character. Individual character is the composite of good habits or virtues and bad habits or vices (Ryan \& Bohlin, 1999). Even though virtues derive from ethos and serve as explicit moral standards, it has very little traction in psychological science (Lapsley \& Narvaez, 2006). Therefore in developing instruments to assess individual character, it is necessary to translate virtues into habits and traits. In this sense it is more logical to ascertain one's character based on related traits and behaviors. Accordingly, we propose behavior oriented self-rating instrument, which should include particular behavior related statements in order to capture the respective virtue related traits or behaviors. However, in formulating action related behavioral statement, special attention should be given to avoid possible confusion between virtues and values. Such statements should reflect particular virtue related habits or traits, and not individual values. As the proposed method assesses individual character at the application level, the less tangible part of the character which retains in application domain of character is also possible to capture. Therefore we believe that content validity of the proposed method is relatively high.

Wright and Goodstein (2007) proposed that character is best, considering both instrumental (means to an end) and terminal (end in and of itself) perspectives. Further we notice that self and self-less aspects of character elaborated by Wright and Goodstein (2007) are coincided with Opatha's (2007) classification of personal virtues and social virtues. Therefore, we propose to consider both personal and social virtues of character in developing instruments to assess individual character. The cardinal Aristotelian virtues include wisdom, justice, temperance, piety, and courage. Over time, as a result of socio economic changes, certain virtues were more emphasized. Hendrix and Berkowitz (2000) as summarized by Barlow et al., (2003)identified 12 attributes for their character assessment model as being primary dimensions of character: integrity, honesty, loyalty, selflessness, compassion, competency, respectfulness, fairness, responsibility and self-discipline, decisiveness, spiritual appreciation, and cooperativeness, for their character assessment model. We notice that Hendrix and Berkowitz model lacks conceptual clarity due to the fact that certain attributes identified in the model are defined as values. As an example, 'spiritual appreciation' is defined as a value which contradicts with fundamental characteristics of virtues. As discussed in this paper, Peterson and Seligman (2004) identify six broad virtue categories to develop their VIA-IS model. However as we pointed out, that VIA-IS model is also potentially suffered as they have approached character as a family of positive characteristics. Further virtue category labeled as 'wisdom and knowledge' is more appropriate to categorize under competency domain rather than as virtue domain. Based on the previous work done by scholars specially Opatha and Teong (2014), we propose ten virtues: honesty, patience, gratitude, humility, respect, benevolence, tolerance, self-discipline, loyalty and caring to be considered in assessing individual character. The above 10 virtues are representing the essential dimensions of individual character which have been ignored in contemporary character studies, i.e. moral and social dimensions as well as self and self-less aspects of character in order to enhance content validity and construct validity of the instrument.

As we discussed in this paper, to abstain from vices is also identified as an important dimension of an individual character. Therefore an effective character assessment tool should be able to capture both individual's level alleviation of vices in addition to level of alignment of virtues. Based on the study done by Opatha (2007) and Opatha (2010) we propose ten major vices: jealousy, deception, selfishness, anger, greed, reprobation, retaliation, hostility, desire for others' things, and lust to be considered for character assessment. As we proposed in capturing virtues, vices related habits and traits should be captured from behavior oriented self-rating instrument which should include respective behavioral statements in order to assess degree of abstaining from the identified vices.

\section{Conclusion and Implications}

Even though the scholarly attention was received recently for the area of individual character, as a result of the moral crisis in the contemporary society, the importance of character and virtues in terms of establishing ethical organizations and society has long been recognized by both western and eastern philosophers. Unfortunately, we noticed that even now both academic studies and popular press have largely ignored the importance of individual character which derived from moral philosophy, and studies are being continued with conceptually shallow terms which may be due to conceptual and empirical ambiguities. In this context, studying character is highly legitimate and vital (Wright \& Huang, 2008). Therefore the purpose of the study was to examine individual character from ontological and epistemological points of view in order to clarify such ambiguities for conceptual and empirical advancement of the construct of individual character. 
Simply, character is individual's deeply engraved symbol which provides moral direction to differentiate right from wrong and good from bad. Character cannot exist without morality, and thus studying character without moral aspect is conceptually infeasible. Further we accept the fact that individual character varies from person to person depending on the person's degree of alignment with virtues and alleviation from vices. However, we all demand from all citizens irrespective of economic or social status, one desirable character that is 'good character' which derived from the individuals who, uphold virtues in high extent as well as who abstain from vices. In theorizing and developing logics on individual character in this paper, we set out to challenge the present self-interested value driven trend of character studies in order to obtain scholar attention on classic account of character which has largely been ignored in current studies. Finally, we believe that this study produces many avenues for the prospective researchers to further study and challenge our study outcome for a further advancement of character and character related theories.

Findings from this study have a number of research implications in theorizing individual character and empirical approach in character related studies. In alignment with recent studies (e.g. Peterson \& Seligman, 2004; Hannah \& Avolio, 2011) our view is that individual character is subject to empirical investigation. However, considering less metaphysical nature of character (Quick \& Wright, 2011) we recommend to study character from character application point of view where even less visible aspects of the character can also be captured, in order to improve content validity of prospective instruments. Even though virtues, praiseworthy habits and praiseworthy traits lay a foundation of individual character, our perspective view is to study character based on related habits and traits as virtues have less traction in psychological point of view. Further, we notice that the term virtue is highly misinterpreted in the recent literature with other terms i.e. value, competency, positive trait. According to Lapsley and Narvaez (2006) we conceptualize virtues as morally driven psychological process which facilitates us to think and act morally. As virtues represent moral domain and other constructs represent different domains i.e. cognitive, skill, it is conceptually infeasible to consider the other constructs as dimensions of character. Further we differ in our theorizing of character as we argue that virtues and vices are two extreme sides of character that an individual can master both aspects simultaneously. Therefore we propose to include both aligning with virtues and abstaining from vices as two dimensions of character.

The research proposals we offer in this paper a wait empirical testing. However, tests of these research proposals depend on the accuracy of prospective empirical instruments which will be developed. Therefore in this paper we logically elaborate process of the development of empirical instrument with higher degree of content and construct validity. Our first proposal is to capture individual's degree of virtue habituation rather than individual's virtue related knowledge. Second proposal is the requirement of both personal virtues and social virtues in assessing individual character. Third proposal is in addition to virtues, effect of vices is to be assessed. Fourth proposal is that character related all attributes need to represent moral domain as character derived from the heart of the morality.

Beyond testing of the proposals, we believe that this paper will inspire prospective researchers to study individual character from different aspects in order to further expand nomological network of the construct. In this sense, we believe that following six questions specially formulated to examine moral account of character are pertinent to peruse systematically and scientifically: i. How might moral virtues influence formation of praiseworthy habits and praiseworthy traits? ii. How might praiseworthy habits influence on praiseworthy traits or vice versa? iii. How might proposed hierarchical relationship of virtues, habits and traits operate? iv. What are the antecedents in formation of moral discipline, moral attachment and moral autonomy? v. Is there a hierarchical order among moral discipline, moral attachment and moral autonomy? vi. How do 'locus', 'transmission' and 'reception' process of character operate in different contexts? Further, it would be interesting to examine how might collective effect of higher management's individual character influence on character of lower level employees in organization setting? Finally, is there a causally or mutually implicative relationship between strength of individual character and eudemonic happiness?

\section{References}

Andersson, L. M., \& Pearson, C. M. (1999). Tit for tat? The spiraling effect of incivility in the workplace. Academy of Management Review, 24(3), 452-471. http://dx.doi.org/10.5465/AMR.1999.2202131

Aristotle, (2000). The Nicomachean ethics trans. R. Crisp, Cambridge: Cambridge University Press. http://dx.doi.org/10.1017/CBO9780511802058

Barlow, C. B., Jordan, M., \& Hendrix, W. H. (2003). Character assessment: An examination of leadership levels. Journal of Business and Psychology, 17(4), 563-584.http://dx.doi.org/10.1023/A:1023408403204

Baumrind, D. (1998). Reflections on character and competence, In A. Colby, J. James \& D. Hart, (eds.) Competence and character through life, Chicago: The University of Chicago Press.

Berkowitz, M. W. (2002). The science of character education. Retrieved from

Beyer, J. M. (1981). Ideologies, value, and decision making in organizations, In P. C. Nystrom \& W. H. Starbuck, (eds.) 
Handbook of Organization Design, 2, 166-202, New York: Oxford University Press.

Collins, J. (2001).Good to great, New York: Harper Business Books.

Covey, S. R. (1999). Why character counts, Readers Digest, 154, 132-135.

Davidson, M., Lickona, T., \& Khmelkov, V. (2008). Smart \& good schools: A new paradigm for high schools character education, In P. N. Larry \& D. Narvaez, (eds.) Handbook of Moral and Character Education, 370-390, London: Rutledge.

Etzioni, A. (1996).The new golden rule, New York: Basic Books.

Facione, P. A. (2000). The disposition toward critical thinking: Its character, measurement, and relationship to critical thinking skills, Informal Logic, 20(1), 61-84.

Garofalo, C. (2003). Towards a global ethic: Perspective on values, training and moral agency. The International Journal of Public Sector Management, 16(7), 490-501.http://dx.doi.org/10.1108/09513550310500373

Giacalone, R. A., \& Promislo, M. D. (2013). Broken When Entering: The Stigmatization of Goodness and Business Ethics Education, Academy of Management Learning \& Education, 12,

86-101. http://dx.doi.org/10.5465/amle.2011.0005A

Hannah, S. T., \& Avolio, B. (2011a). Leader character, ethos, and virtue: Individual and collective considerations. The Leadership Quarterly, 22, 989-994. http://dx.doi.org/10.1016/j.leaqua.2011.07.018

Hannah, S. T., \& Avolio, B. (2011b). The locus of leader character. The Leadership Quarterly, 22, 979-983. http://dx.doi.org/10.1016/j.leaqua.2011.07.016

Hendrix, W. H., \& Berkowitz, M. W. (2000). Development of an attitudinal and behavioral character development assessment system, Paper presented at the $26^{\text {th }}$ Annual Association of Moral Education Conference, Glasgow, Scotland.

Himmelfarb, G. (1994).The de-moralization of society: From Victorian virtues to modern values, New York: Vintage Books.

http://media.hoover.org/sites/default/files/documents/0817929622_43.pdf.

Hunter, J. W. (2000).The death of character: Moral education in an age without good or evil, New York: Basic Books.

James, W. (1920). In Henry, J. (ed.) The letters of William James, Boston: The Atlantic Monthly Press. http://dx.doi.org/10.1037/11011-000

Lapsley, D. K., \& Narvacz, D. (2006). Character education, In Renninger, K. A. \& Siegel, I. E. (eds), Handbook of Child Psychology, 4, New Jersey: John Wiley \& Sons.

Lickona, T. (1991).Educating for character: How our schools can teach, respect and responsibility, New York: Bantam Books.

McCullough, M. E., \& Snyder, C. R. (2000). Classical sources of human strength: revisiting an old home and building a new one. Journal of Social and Clinical Psychology, 19(1), 1-10.http://dx.doi.org/10.1521/jscp.2000.19.1.1

Neubert, M. J., Carlson, D. S., Kacmar, K. M., \& Chonko, L. B. (2009). The virtuous influence of ethical leadership behavior: Evidence from the field. Journal of Business Ethics, 90, 157-170. http://dx.doi.org/10.1007/s10551-009-0037-9

Opatha, H. H. D. N. P. (2007). Individual character: A perspective. Sri Lankan Journal of Human Resource Management, 1(1), 1-14.

Opatha, H. H. D. N. P. (2010).Personal Quality., Sri Lanka: Department of Human Resource Management.

Opatha, H. H. D. N. P., \& Teong, L. K. (2014).Enhancing your personal Q, Malaysia: Universiti Utara.

Park, N., \& Peterson, C. (2009) Character strengths: Research and practice. Journal of College \& Character, 10(4), 1-10. http://dx.doi.org/10.2202/1940-1639.1042

Park, N., Peterson, C., \& Seligman, M. (2004).Strengths of character and well-being.Journal of Social and Clinical Psychology, 23(5), 603-619. http://dx.doi.org/10.1521/jscp.23.5.603.50748

Pearson, C., \& Porath, C. L. (2005). On the nature, consequences and remedies of workplace incivility: No time for "nice"? Think again. Academy of Management Executive,

19(1), 7-18. http://dx.doi.org/10.5465/AME.2005.15841946

Peterson, C., \& Park, N. (2006).Character strengths in organizations.Journal of Organizational Behavior, 27, 1149-1154. 
http://dx.doi.org/10.1002/job.398

Peterson, C., \& Seligman, M. E. P. (2004).Character strengths and virtues: A handbook and classification, New York, Oxford University Press.

Quick, J. C., \& Wright, T. A. (2011).Character-based leadership, context and consequences. The Leadership Quarterly, 22, 984-988. http://dx.doi.org/10.1016/j.leaqua.2011.07.017

Rokeach, M. (1973). The nature of human values, New York, The Free Press. TRI

Ryan, K., \& Bohlin, K. E. (1999).Building character in schools: Practical ways to bring moral instruction to life, San Francisco: Jossey Bass.

Sarros, J. C., Cooper, B. K., \& Hartican, A. M. (2006). Leadership and character. Leadership \& Organization Journal, 27(8), 682-699. http://dx.doi.org/10.1108/01437730610709291

Sherman N, (1989). The Fabric of Character: Aristotle's Theory of Virtue, New York: Oxford University Press

Thorndike, E. L. (1940).Human nature and social order, New York, MacMillan.http://dx.doi.org/10.1037/14654-000

Thun, B., \& Kelloway, E. K. (2011). Virtuous leaders: Assessing character strengths in the workplace. Canadian Journal of Administrative Science, 28(3), 270-283. http://dx.doi.org/10.1002/cjas.216

Tranfield, D., Denyer, D., \& Smart, P (2003). Towards a methodology for developing evidence-informed management knowledge by means of systematic review, British Journal of Management, 14(3), 207-222, http://dx.doi.org/10.1111/1467-8551.00375

Veenhoven, R. (1994). Is happiness a trait? Social Indicators Research, 32, 101-160. http://dx.doi.org/10.1007/BF01078732

Wright, T. A., \& Goodstein, J. (2007). Character is not dead in management research: A review of individual character and organizational-level virtue. Journal of Management, 33, 928-958. http://dx.doi.org/10.1177/0149206307307644

Wright, T. A., \& Huang, C. C. (2008). Character in organizational research: Past directions and future prospects. Journal of Organizational Behaviour, 29, 981-987. http://dx.doi.org/10.1002/job.521

Wright, T. A., \& Lauer, T. L. (2013). What is character and why it really does matter. Organizational Dynamics, 42 , 25-34. http://dx.doi.org/10.1016/j.orgdyn.2012.12.004

Wright, T. A., \& Quick, J. C. (2011). The role of character in ethical leadership research. The Leadership Quarterly, 22, 975-978. http://dx.doi.org/10.1016/j.leaqua.2011.07.015

Wright, T. A., \& Wright, V. P. (2001). Fact or fiction: The role of (In) civility in organizational research. The Academy of Management Review, 26(2), 168-170. http://dx.doi.org/10.5465/AMR.2001.4378005

Yu, J. (1998). Virtue: Confucius and Aristotle. Philosophy East and West, 48(2), 323-347. http://dx.doi.org/10.2307/1399830

\section{Copyrights}

Copyright for this article is retained by the author(s), with first publication rights granted to the journal.

This is an open-access article distributed under the terms and conditions of the Creative Commons Attribution license (http://creativecommons.org/licenses/by/3.0/). 